\title{
PENGAJARAN MATEMATIKA TERPADU DENGAN MENGGUNAKAN MEDIA KARTU KERJA DI KELAS MIXED ABILITY
}

Oleh: Muhammad lqbal *)

\section{Abstrak}

Penulisan ini mencoba menawarkan suatu gagasan untuk mengatasi masalah esensial yang umumnya dihadapi oleh para guru mata pelajaran, khususnya Matematika baik di SD, SLTP maupun di SLTA, seperti:

1. Adanya penilaian negatif terhadap matematika. sebagai suatu mata pelajaran yang sulit, tidak aktual dan kurang menarik, sehingga para siswa kurang berminat atau bergairah untuk mempelajarinya.

2. Kenyataan menunjukkan bahwa siswa di suatu kelas di sekolah kita, umumnya heterogen atau mempunyai kemampuan intelektual yang bervariasi (Mixed Ability). Kenyataan-kenyataan tersebut jelas merupakan faktor penghambat usaha guru untuk mencapai hasil pengajaran yang maksimal.

Dalam upaya menumbuhkan minat belajar siswa dan upaya pengembangan metode pengajaran matematika di kelas-kelas "mixed ability", penulis memperkenalkan media pembelajaran yang efektif dan menyenangkan (enjoyable), yaitu "KARTU KERJA". Kartu kerja sebagai media pengajaranan alternatif memuat soal-soal / latihan matematika dalam tingkatantingkatan tertentu, seperti tingkat pengembangan, latihan/ penerapan, dan pengayaan untuk melayani semua siswa sesuai dengan tingkat kemampuan intelektualnya.

*) Muhammad lqbal, S.Pd., adalah Guru Matematika SLTPN I RasanaE Bima, Nusa Tenggara Barat., Pemenang Lomba Guru Paling Inovatif tingkat Nasonal. 
Dengan demikian, siswa dapat belajar secara mandiri (self learning), kemajuan belajarnya tidak terikat, maju secara berkelanjutan (independent) serta pemahaman konsep akan menjadi mantap karena merupkan hasil kerja mandiri melalui pendekatan induktif dan generalisasi.

Berdasarkan hasil pengamatan empiris, terlihat adanya pengaruh dan perkembangan yang berarti terhadap siswa-siswa setelah menggunakan kartu kerja, seperti adanya kegairahan dan keaktifan siswa menyelesaikan sejumlah kartu kerja, kepuasan siswa yang berkemampuan lebih dapat menyelesaikan lebih banyak kartu, serta kepuasan siswa yang berkemampuan kurang/lemah setelah mendapat bimbingan individual dari guru mereka.

\section{PENDAHULUAN}

\section{A. Latar Belakang}

Matematika adalah suatu alat untuk menngembangkan cara berfikir dan bernalar. Matematika diperlukan dalam kehidupan sehari-hari dan untuk perkembangan sains dan teknologi. Akibatnya matematika wajib diberikan sebagai bekal bagi setiap peserta didik sejak dari SD.

Namun, di balik peranan dan manfaat matematika tidak sedikit orang masih menganggap Matematika sebagai ilmu yang tidak menarik/tidak menyenangkan, pelajaran yang sulit dan tidak aktual (Druxes, 1986). Demikian pula bagi para siswa pada umumnya banyak yang kurang menyenangi pelajaran Matematika, sebagaimana pandangan berikut: "Pelajaran Matematika sampai sekarang masih menjadi momok bagi siswa" (Karya Bhakti, No. 17/XIV. Juni 1993). Juga bukan hanya siswa, orang tuapun ikut gusar, jika sedang menyertai anaknya belajar Matematika (kompas, 17 Juni 1990). 
Di sisi lain, kenyataan menunjukkan bahwa siswa di suatu kelas di sekolah kita umumnya heterogen, artinya mempunyai kemampuan intelektual berbeda-beda (bervariasi) atau yang dikenal "mixed ability" dan penyampaian materi yang sama untuk semua siswa pada waktu yang sama mengakibatkan terhambatnya kemajuan belajar bagi siswa yang berkemampuan lebih baik.

Berkaitan dengan masalah di atas, penulis merasa tergugah untuk turut memberikan sumbangan pemikiran dan gagasan dalam dunia pendidikan, khususnya membantu rekan-rekan guru dalam mengatasi kesulitan dan hambatan dalam pelajaran matematika pada kelas-kelas mixed ability dengan mengembangkan strategi belajar tuntas (mastery learning) menggunakan media "kartu kerja" sehingga proses belajar mengajar akan lebih efektit; terpadu dan menyenangkan.

\section{B. Identifikasi Masalah}

1. Apakah dengan menggunakan kartu kerja, pembelajaran Matematika akan lebih efektif dan menyenangkan?

2. Apakah pengajaran Matematika dengan media Kartu Kerja dapat menjamin ketuntasan belajar siswa?

3. Mengapa perlu dikembangkan Kartu Kerja padahal sudah ada Lembar Kerja Siswa (LKS)?

4. Apakah para guru Matematika memiliki kemampuan dan keterampilan membuat dan menggunakan Kartu Kerja secara efektif'?

5. Mengapa penggunaan Kartu Kerja hanya efektif untuk kelaskelas Heterogen? Lalu bagaimana bila diterapkan di kelas Homogen?

\section{Rumusan Masalah}

Berdasarkan permasalahan di atas, maka ada 4 (empat) masalah yang dapat dirumuskan yaitu:

1. Bagaimanakah teknik penbuatan Kartu Kerja? 
2. Bagaimanakah teknik penggunann Kartu Kerja sehingga mewujudkan kegiatan belajar mengajar yang efektif dan menyenangkan?

3. Apakah penggunaan media Kartu Kerja dapat mempertinggi mutu proses dan hasil belajar mengajar di sekolah?

\section{Tujuan Penulisan}

1. Memberi informasi kepada guru matematika khususnya tentang manfaat Kartu Kerja sebagai media altenatif dalam melayani kebutuhan belajar (needs) siswa di kelas mixed ability.

2. Memotivasi rekan-rekan guru untuk mengembangkan daya inovatif dan kreativitas dalam upaya peningkatan mutu proses kegiatan belajar mengajar di kelas.

\section{E. Manfaat Penulisan}

Penggunaan media Kartu Kerja ini diharapkan dapat memberikan beberapa manfaat, baik bagi siswa maupun guru.

1. Manfaat bagi siswa:

- Menumbuhkan motivasi dan minat belajar siswa terhadap matematika.

- Melatih kemandirian siswa dan memungkinkan siswa maju menurut kemampuan masing-masing (self paced learning).

2. Manfaat bagi guru:

- Kegiatan belajar mengajar akan mudah terkontrol

- Kegiatan belajar mengajar akan lebih efektif terpadu dan menyenangkan.

\section{KAJIAN PUSTAKA}

Salah satu asas mengajar yang kita kenal adalah "asas perbedaan individual". Kaitan asas ini dalam praktek telah lama dipikirkan para ahli kependidikan. Mereka banyak memikirkan tentang bentukbentuk pengajaran yang dapat memberi kesempatan kepada siswa belajar secara individul. Meskipun hingga saat ini masih banyak 
kita lihat guru mengajar dengan berlandaskan kemampuan secara "pukul rata". Tanpa mempertimbangkan kemampuan masingmasing individu.

Berbagai hasil penelitian membuktikan bahwa kemampuan dasar atau kemampuan potensial (intelegensi dan bakat) seseorang berbeda-beda satu sama lain. Tidak ada individu mempunyai inteligensi atau bakat yang sama dalam berbagai bidang. Meskipun kita terima pengelompokkan siswa berdasarkan kategorisasi prestasi (tinggi-sedang-rendah), itu hanyalah suatu pendekatan saja. Hakekatnya setiap siswa berbeda secata individual baik dalam hal prestasi maupun kemampuan potensialnya (Muhammad Ali, 1983 : 94).

Menekankan pentingnya memperhatikan perbedaan individual dalam pengajaran, sungguh suatu keharusan. Namun, demikian dalam praktek hal ini masih merupakan sesuatu yang ideal. Untuk mewujudkannya guru harus memahami dan mampu mengembangkan strategi belajar mengajar dengan pendekatan individual.

Strategi belajar mengajar individual di samping rnemungkinkan setiap siswa dapat belajar sesuai dengan kemampuan potensialnya, juga memungkinkan setiap siswa dapat menguasai seluruh bahan pelajaran secara penuh. Kemampuan memperoleh hasil secara penuh ini merupukan ide tersendiri yang melandasi berbagai sistem pengajaran individual. Ide ini dikenal dengan istilah "mastery learning" atau "belajar tuntas".

Benyamin S. Bloom (1963) sebagai peletak dasar strategi belajar tuntas, memandang mastery sebagai kemampuan siswa untuk menyerap inti pengajaran yang telah diberikan ke dalam suatu keseluruhan. Strategi pengajaran Model Bloom, merupakan sistem pengajaran yang dapat mengantarkan siswa mencapai taraf penguasaan penuh (mastery) yang dilakukan dalam situasi kelompok, untuk menyesuaikan dengan berbagai "perbedaan 
individual".

Berdasarkan hasil penelitian James Block (1971 -1 973), strategi belajar tuntas yang dikembangkan oleh Bloom ternyata sangat efektif, dapat membangkitkan minat siswa belajar dan bersikap positif terhadap kemampuannya untuk belajar melalui pendekatan belajar tuntas (Gronlund, 1974 : 20, dalam Muhammad Ali, 1983 : 103).

Seirama dengan strategi pengajaran Model Bloom, adalah Personalized System of Instruction (PSI) yang dikembangkan oleh Fred S. Keller (1968), terutama digunakan di tingkat Universitas, untuk mengatasi sistem kuliah konvensional, seperti yang dikutip oleh Nasution (1982: 70 ) berikut ini :

“.......sistem ini memberi perhatian yang khusus kepada setiap pelajar memberi mereka kesempatan untuk maju menurut kecepatan masing-masing dan diharuskan menguasai satuan pelajaran sebelum diperkenankan untuk mempelajari pelajaran berikutnya. Tes banyak memberi penilaian sebagai feed back dengan bantuan mahasiswa yang sudah lebih maju dari yang memerlukan bantuan..... Selain memeriksa tes, mahasiswa senior dimanfaatkan juga untuk berperan sebagai instructional manager dan terutama untuk memberikan motivasi dan stimulasi kepada mahasiswa dalam belajar".

Menurut Nasution (1982: 72), beberapa ciri penting dari pengajaran dengan sistem PSI adalah sebagai berikut.

1. Memungkinkan siswa maju menurut kemampuan masingmasing (self paced learning).

2. Adanya persyaratan penguasaan yang sempurna bagi setiap unit pelajaran sebelum maju ke unit pelajaran berikutnya

3. Menggunakan kuliah dan demonstrasi sebagai alat untuk memberikan motivasi kepada siswa. 
4. Komunikasi guru siswa ditekankan pada penggunaan bahanbahan tertulis dalam bentuk program.

5. Menggunakan sistem proctor, yakni memberi test secara berulang-ulang untuk memberikan penilaian secara cepat dan sebagai catu balik bagi pemberian bantuan kepada siswa yang membutuhkan.

6. Menggunakan sistem tutor, yakni siswa pandai memberi bimbingan belajar kepada siswa yang kurang/lemah, sehingga semua siswa dapat mencapai taraf penguasaan penuh terhadap unit pelajaran yang dipelajari.

7. Memungkinkan adanya aspek personal dan sosial dalam proses pendidikan.

\section{PEMBAHASAN}

\section{A. Tuntutan Kurikulum / GBPP dan Kenyataan di Lapangan}

Seorang guru mempunyai pandangan sendiri tentang apa yang diharapkan dari hasil suatu pengajaran di kelas yang berbedabeda tingkat intelektual (mixed ability).

Contoh: Setiap siswa pada suatu kelas harus:

1. Mencapai target kemampuan minimal, yaitu mereka harus menguasai bagian yang fundamental dari suatu topik/ konsep.

2. Mampu mengerjakan soal-soal tes yang sifatnya sumatif sehingga perbedaan hasil belajar antara siswa yang pintar dan siswa yang kurang pintar tidak terlalu berbeda tajam.

Memang beralasan bila seorang guru mengemukahan harapanharapannya seperti tersebut di atas. Di sisi lain kenyataan umum yang kita hadapi:

1. Kurikulum/GBIPP Matematika di Indonesia, memuat materi minimal yang harus dikuasai oleh siswa sesuai jenjangnya. Pada umumnya kita menganggap bahwa semua siswa dalam suatu kelas mempunyai kemampuan intelektual yang relatif sama, sehingga pengajarannya kurang memperhatikan adanya perbedaan kemampuan intelektual 
siswa. Kenyataan menunjukkan bahwa siswa di suatu kelas di sekolah kita umumnya heterogen atau mempunyai kemampuan intelektual yang bervariasi.

2. Pada akhir semester/catur wulan, siswa-siswa yang mempunyai perbedaan tingkat intelektual itu harus mengikuti dan mengerjakan soal-soal sumatif yang sama.

Kenyataan-kenyataan tersebut di atas jelas merupakan faktorfaktor penghambat usaha guru untuk mencapai hasil pengajaran yang maksimal.

Kesenjangan antara tuntutan kurikulum dan kenyataan adanya perbedaan kemampuan siswa di lapangan perlu menjadi bahan pemikiran kita bersama. Salah satu upaya yang dipikirkan adalah mencari suatu bentuk pendekatan tentang pengembangan pengajaran yang sesuai kelas-kelas "mixed ability".

Bagi seorang guru yang kreatif, selalu berupaya untuk meningkatkan efektivitas dalam kegiatan belajar mengajar. Efektivitas dan efisiensi kegiatan belajar mengajar sangat dipengaruhi oleh penguasaan guru terhadap bahan ajar dan keterampilan/cara mengajar (instructional design) termasuk di dalamnya penggunaan media pengajaran yang kini semakin berkembang secara cepat (Sive, 1981, Henich et al,. 1989. Peake dan Peterson, 1989, dalam Soekartawi, 1985 : 9).

\section{B. Alasan Penggunaan Kartu Kerja}

Fungsi utama dari media adalah sebagai alat bantuan sarana untuk mencapai tujuan pengajaran. Melalui penggunaan media pengajaran diharapkan dapat mempertinggi kualitas proses belajar mengajar yang pada akhirnya dapat mempertinggi kualitas hasil belajar siswa.

Dalam upaya mencapai hasil pengajaran yang maksimal pada kelas-kelas mixed ability, Kartu Kerja merupakan salah satu 
media pengajaran yang didasarkan atas kebutuhan belajar (needs) siswa sesuai dengan tingkat kemampun intelektualnya.

Beberapa alasan penggunaan Media Kartu Kerja, yaitu:

1. Berkenaan dengan manfaat media Kartu Keria dalam proses belajar siswa, seperti:

a. Pengajaran akan lebih menarik perhatian siswa, sehingga dapat menumbuhkan motivasi belajar.

b. Bahan pelajaran akan lebih jelas maknanya, sehingga dapat lebih dipahami oleh para siswa dan memungkinkan siswa mungusai tujuan pengajaran akan lebih baik.

c. Metode mengajar akan lebih bervariasi, tidak terkesan verbalisme, sehingga siswa tidak bosan dan guru tidak kehabisan tenaga.

d. Siswa lebih banyak melakukan kegiatan belajar, di samping melatih/membina kemandirian dan mengembangkan kreativitas siswa.

2. Berkenaan dengan taraf berpikir siswa. Taraf berpikir manusia mengikuti tahap perkembangan, dimulai dari berpikir kongkret menuju ke berpikir abstrak, dan berpikir sederhana menuju ke berpikir kompleks. Terlebih pelajaran matematika sarat dengan ide-ide atau konsep-kunsep abstrak, yang penalarannya bersifat dedukatif formal, sehingga untuk penyajian di kelas penggunaan media bantu mutlak adanya.

Jadi Kartu Kerja selain berfungsi untuk menympaikan pesan, juga berfungsi untuk menarik perhatian, memperjelas ide, mengilustrasikan atau menghiasi fakta yang mungkin cepat dilupakan.

Sesungguhnya, antara Kartu Kerja dan Lembar Kerja Siswa (LKS) mempunyai beberapa perbedaan dan persamaan: 
Tabel: Perbedaan dan Persamaan antara Kartu Kerja dan Lambar Kerja Siswa (LKS).

\begin{tabular}{|c|l|l|l|}
\hline NO. & \multicolumn{1}{|c|}{ ASPEK } & KARTU KERJA & $\begin{array}{l}\text { LEMBAR KERJA } \\
\text { SISWA (LKS) }\end{array}$ \\
\hline 1. & $\begin{array}{l}\text { Pengembangan } \\
\text { Materi }\end{array}$ & Ada & Ada \\
2. & Latihan/pemantapar & Ada & Ada \\
3. & Pengayaan & Ada & Tidak Ada \\
4. & Biaya & Murah & Mahal \\
5. & Pemakaian & Berulang Kali & Satu Kali \\
6. & Pemikiran Siswa & UmumnyaBebas & Terarah \\
7. & Waktu & Tergantung & Singkatnya \\
8. & Bimbingan Guru & Kemampuan & 15 Menit \\
9. & Ruang Lingkup & Luas & Ada \\
\hline
\end{tabular}

Sumber: Materi LKGI/SPKG Matematika. Bagian Proyek PA II A- PKG, Depdikbud Kanwil NTB, 1991.

\section{Proses Pembuatan dan Penyusunan Kartu Kerja}

Secara teknis proses pembuatan Kartu Kerja tidak jauh berbeda dengan pembuatan LKS. Namun, secara prinsip keunggulan Kartu Kerja, di samping bahan / biaya pembuatannya yang relatif murah, juga proses pembuatannya cukup mudah.

Langkah-langkah pembuatan dan penyusunan Kartu Kerja, yaitu:

1. Untuk satu kali pertemuan, seperangkat Kartu Kerja dapat terdiri dari 3 - 7 lembar kartu.

2. Ukuran kertas yang digunakan disesuaikan dengan kebutuhan, idealnya kertas ukuran kwarto (A4).

3. Buatlah bingkai tulisan, misalnya berukuran $15 \mathrm{~cm} \times 22 \mathrm{~cm}$.

4. Susunlah seperangkat Kartu kerja, kemudian diperbanyak atau di foto copy sebanyak kebutuhan (perorangan atau kelompok kecil). Sebaiknya satu Kartu Kerja untuk satu 
orang, tujuannya untuk melatih kemadirian siswa.

5. Beberapa hal yang perlu diperhatikan dalam penyusunan Kartu Kerja, yaitu:

a. Isi/Topik; berisi materi pelajaran matematika berdasarkan Pokok Bahasan yang ada dalam GBIPM/ Kurikulum yang berlaku.

b. Bahasa/Informasi; menggunakan Bahasa Indoensia yang baik dan benar, yang dapat dimengerti oleh siswa.

c. Bentuk dan Sistematika; untuk satu topik dapat dibuat serangkaian Kartu Kerja dalam bentuk tingkatantingkatan tertentu, seperti: mudah, sedang dan sukar atau tingkat pengembangan, latihan/penerapan dan pengayaan.

d. Pengetahuan Prasyarat; yaitu pengetahuan berupa konsep yang mendasari materi yang akan disajikan.

6. Beberapa hal yang perlu dicantumkan pada Kartu Kerja, antara lain:

a. Nomor urut Kartu Kerja,

b. Judul Materi/Topik.

c. Uraian singkat tentang masalah atau uraian tentang konsep materi yang diperlukan untuk membantu penyelesaian saal-soal.

d. Uraian tugas atau pertanyaan yang harus dijawab oleh siswa.

c. Gambar-gambar pendukung, untuk memperjelas ide konsep, merangsang minat/motivasi dan membantu ingatan siswa.

Secara umum, Kartu Kerja terdiri dari 3 (tiga) tingkatan, yaitu:

1. Tingkatan Pertama, terdiri dari soal-soal yang bersifat pengembangan dari materi esensial (Kartu berwarna kuning)

2. Tingkatan Kedua, terdiri dari soal-soal latihan yang bersifat pemantapan dan penerapan (Kartu berwunrna hijau)

3. Tingkatan Ketiga, terdiri dari soal-soal yang bersifat pengayaan dalam bentuk investigasi, problem solving, tekateki atau permainan (Kartu berwarna merah). 


\section{Penggunaan Kartu Kerja Dalam Pengajaran Matematika}

1. Sebelum Kartu Kerja pertama dibagikan kepada siswa, guru perlu memberikan:

a. Apersepsi, motivasi dan introduksi;

b. Penjelasan singkat tentang materi yang mendasari uraian kegiatan atau contoh yang terdapat dalam Kartu Kerja.

2. Bila Kartu Kerja sudah dibagikan, guru hendaknya memantau kemajuan belajar siswa dengan tujuan:

a. Jika ada siswa yang dapat menyelesaikan Kartu Kerja dengan benar, guru segera memberikan Kartu Kerja berikutnya, demikian seterusnya.

b. Jika ada siswa yang mengalami kesulitan, guru hendaknya memberikan bimbingan atau pengarahan seperlunya, dalam arti tidak langsung pada penyelesian masalah yang dihadapinya. Dalam hal ini jelas dituntut kemampuan guru, terutama dalam penggunaan keterarnpilan / teknik bertanya.

c. Bila ada siswa yang telah mencapai "Top Record", yakni telah menyelesaikan semua Kartu Kerja dengan sempurna atau memenuhi standar penguasaan (Standard Mastery) secara rata-rata diatas $80 \%$ dapat dimantaatkan sebagai "Tutor Sebaya" untuk membantu/membimbing rekan siswa yang memerlukan bantuan.

3. Sebelum jam pelajaran berakhir, guru harus mencatat keberhasilan siswa dalam menyelesaikan Kartu Kerja, sudah berapa lembar Kertu Kera yang telah diselesaikan oleh siswa tersebut pada hari itu. Pencatatan hasil pekerjaan siswa tersebut dituliskan pada Kartu yang dikenal dengan "Matrix Record" Untuk itu kita juga harus mempersiapkan Kunci Jawaban agar dapat dengan mudah memeriksa pekerjaan siswa. 
Dengan demikian siswa dapat belajar secara mandiri (Self Learning), yang berkemampuan lebih baik akan dapat menyelesaikan lebih banyak Kartu Kerja, dia tidak perlu menunggu temannya yang belum selesai. Jadi kemajuan belajarnya ditentukan oleh dirinya sendiri.

Pengorganisasian Kartu Kerja yang baik, akan membawa siswa melalui pengalaman belajar yang sesuai dan terkoordinir, dari satu konsep ke konsep berikutnya. Kondisi ini akan sangat membantu siswa dalam membentuk struktur matematika.

Pemahaman konsep harus diikuti latihan-latihan. untuk memberikan keyakinan diri, bahwa konsep yang dipelajari benar-benar dipahami secara mantap sebelum pindah ke konsep-konsep berikutnya.

Lewat media Kartu Kerja, matematika dikenalkan sebagai keterampilan di dalam kehidupan sehari-hari yang sangat benmanfaat melalui konteks yang akrab dan menarik bagi siswa. Hal ini akan sangat berguna untuk membangkitkan motivasi yang lebih tinggi dan pandangan positif terhadap matematika.

Siswa yang belajar tidak sekedar menirukan apa yang dilakukan oleh guru mereka, melainkan secara aktif timbul upaya untuk berbuat atas keyakinannya sendiri. Kiranya inilah salah satu implernentasi dari sistem "Belajar Tuntas" (Mastery Learning).

\section{E. Keuntungan Penggunaan Kartu Kerja}

Ada beberapa keuntungan penggunaan Kartu Kerja dalam pengajaran Matametika, antara lain:

1. Siswa termotivasi untuk menyelesaikan masalah-masalah berdasarkan pengalarnan sendiri.

2. Prinsip psikologis terpenuhi, karena pemahaman konsep melalui pendekatan induktif/generalisasi.

3. Pemahaman konsep akan menjadi mantap, karena merupakan hasil kerja mandiri dan memungkinkan siswa 
untuk mentransfer pengalaman belajarnya ke situasi lain.

4. Kemajuan belajar siswa tidak terikat, maju secara berkelanjutan (Independent).

5. Menumbuhkan rasa percaya diri.

6. Menumbuhkan rasa kerja sama dalam pertukaran ide-ide.

7. Mendorong siswa untuk kreatif.

8. Membantu ingatan siswa. Seseorang cenderung mudah mengingat hal-hal yang ada kesannya. Dengan kehadiran gambar-gambar pendukung, konsep-konsep matematika yang sarat dengan simbol-simbol, aturan-aturan dan rumusrumus akan mudah diingat oleh siswa.

Tetapi satu hal yang perlu kita ketahui, bahwa tidak ada media pendidikan atau media pengajaran yang dapat menggantikan kedudukan guru $100 \%$, serta tidak ada media pengajaran yang merupakan media tunggal untuk mmcapai semua tujuan pelajaran.

Demikian pula Kartu Kerja memiliki keterbatasan. Sehubungan dengan itu, ada beberapa hal yang perlu diperhatikan, seperti: 1. Memerlukan keterampilan guru dalam merakit Kartu Kerja.

2. Memerlukan kemampuan ekstra atau teknik guru untuk membimbing siswa dalam kelas besar, apalagi bila kemampuan siswa sangat berbeda.

3. Koordinasi yang kurang baik, dapat mengakibatkan siswa hanya bermain-main atau meminta bantuan temannya untuk menyelesaikannya. Untuk itu selama Kegiatan Belajar Mengajar berlangsung guru tetap berperan sebagai motivator dan fasilitator.

4. Tidak dapat melingkupi semua topik, ada topik yang sulit dituangkan dalam bentuk Kartu Kerja. 


\section{PENUTUP}

A. Kesimpulan

Dari uraian di muka dapat ditarik beberapa kesimpulan, sebagai berikut:

1. Pengajaran matematika dengan menggunakan media Kartu Kerja merupakan teknik pemberian tugas/latihan kepada siswa sesuai dengan kebutuhan dan tingkat kemampuan intelektualnya.

2. Penggunaan Kartu Kerja dalam pengajaran matematika merupakan salah satu bentuk pendekatan keterampilan proses dan memiliki kadar CBSA yang cukup tinggi serta sangat cocok/efektif untuk diterapkan pada kelas-kelas "Mixed Ability"

3. Penggunaan media Kartu Kerja merupakan sesuatu yang baru bagi anak, sehingga dapat menarik perhatian, menumbuhkan motivasi dan minat belajarnya, yang akhirnya dapat meningkatkan kualitas proses dan hasil belajar anak menuju ketuntasan belajar (Mastery Learning).

4. Kartu Kerja yang dilengkapi gambar-gambar pendukung, ternyata lebih efektif dalam membantu ingatan siswa, sebab seseorang akan lebih mudah mengingat hal-hal yang ada kesannya.

\section{B. Saran-saran}

1. Agar penggunaan Kartu Kerja dapat meningkatkan efektivitas dan efisiensi kegiatan belajar mengajar, maka perlu diperhatikan hal-hal sebagai berikut:

a. Diperlukan kreativitas dan keterampilan guru dalam merakit Kartu Kerja.

b. Diperlukan kemampuan guru dalam membimbing siswa dalam kelas besar yang heterogen, yaitu dengan cara membeikan bimbingan/pengarahan seperlunya. Dalam hal ini diperlukan kemampuan guru terutama dalam penggunaan "Teknik Bertanya" 
c. Dalam kegiatan belajar mengajar, seorang guru berperan sebagai motivator dan fasilitator.

2. Kepada rekan-rekan guru diharapkan untuk dapat menggunakan Kartu Kerja sebagai suatu media/pendekatan alternatif dalam kegiatan belajar mengajar. Dengan harapan bahwa penggunaan media/pendekatan secara bervariasi dan berimbang dapat membantu proses pencapaian tujuan pengajaran yang ditetapkan.

\section{DAFTAR PUSTAKA}

Ali Muhammad, (1988). Guru Dalam Proses Belajar Mengajar, Bandung; Sinar Baru Algensindo.

Bagian Proyek PA II A - PKG NTB, (1991). Materi IKGI/SPKG Matematika, Depdikbud Kanwil NTB.

Depdikbud, (1983). Kurikulum Pendidikan Dasar Sekolah Lanjutan Tingkat Pertama, GBPP Mata Pelajaran Matematika Jakarta.

Hamzah, Amir, (1994), Beban Belajar Mengajar di Sekolah Dasar, Suara Nusa : 5

September.

Hartojo, (1990). Matematika Rekreasi I (Teka -Teki), Klaten Utara : Intan Pariwara.

Murrary, Edward, J. (al1964) Motivation and Emotion, Pretice Hall.

Nasution, S., (1984), Beberapa Pendekatan Dalam Proses Belajar Mengajar, Jakarta:

Bina Aksara.

Ruseffendi, E.T,. (1984), Dasar-dasar Maternatika Modern dan Komputer untuk Guru,(Ed.

IV), Bandung : Tarsito.

Scottish Mathematics Group, (1991). Teori dan Perapan Matematika SMP IA, 2B, 2A dan $3 A$ (terjemahan), Jakarta : Erangga.

Sudjana, Nana dan Ahmad Rivai, (1990). Media Pengajaran, Bandung : Sinar Baru, Bandung.

Soekartawi, (1985). Meningkatkan Efektivitas Mengajar, Jakarta : PT. Dunia Pustaka Jaya.

Wardhana, Datta, (1983). Pendekatan Integratif Belajar Tuntas dan Keterampilan Proses, .Jawa Pos : 2 September.

Winkel, W.S., (19983). Psikologi Pendidikan dan Evaluasi Belajar, Jakarta: Gramedia. 
Lampiran 1: Contoh Format Matrix Records.

MODEL : M.01

\section{MATRIX RECORD}

Nama Siswa

$\mathrm{N}$ IS

Kelas/Cawu

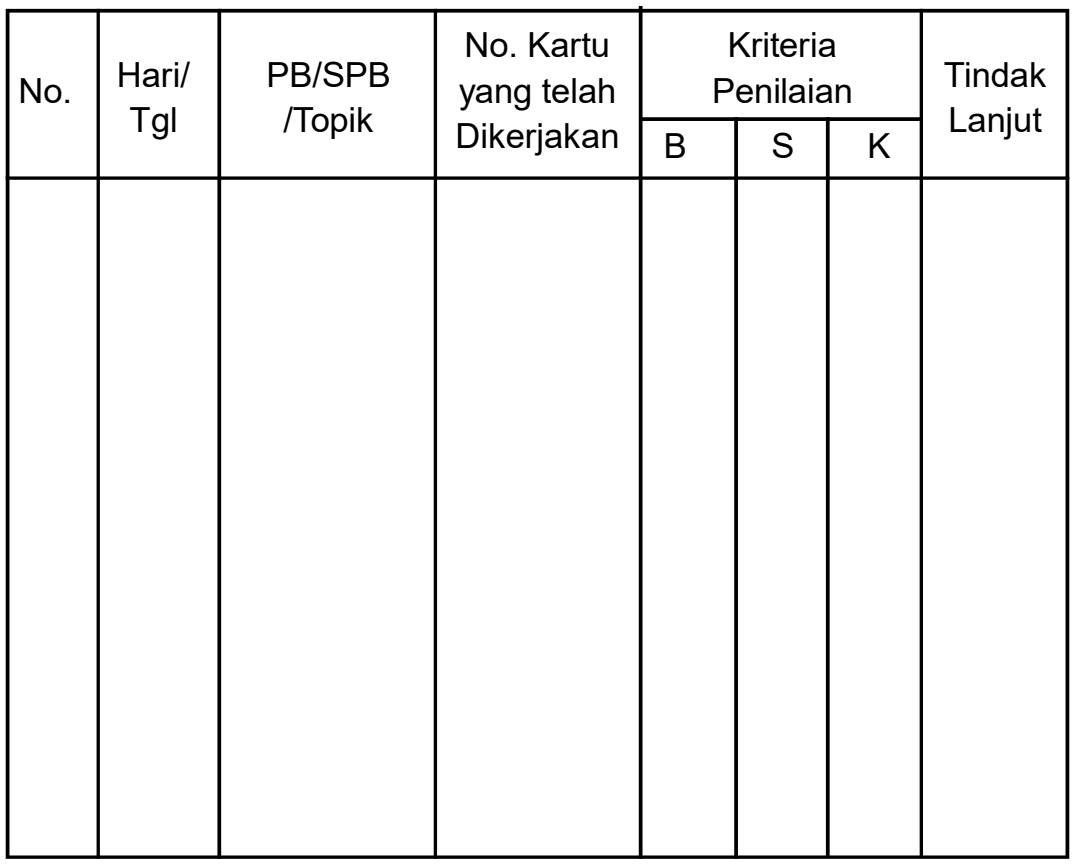

\section{Keterangan:}

$B=$ Baik $(80-100)$

$S=$ Sedang $(70-79)$

$\mathrm{K}=$ Kurang $(60-69)$

\section{Guru Mata Pelajaran}

NIP.: 
Lanjutan Lampiran 1: Contoh Format Matrix Records.

MODEL : M.02

\section{MATRIX RECORD}

Mata Pelajaran :

Pokok Bahasan :

SPB/No. RP

Kelas/Cawu

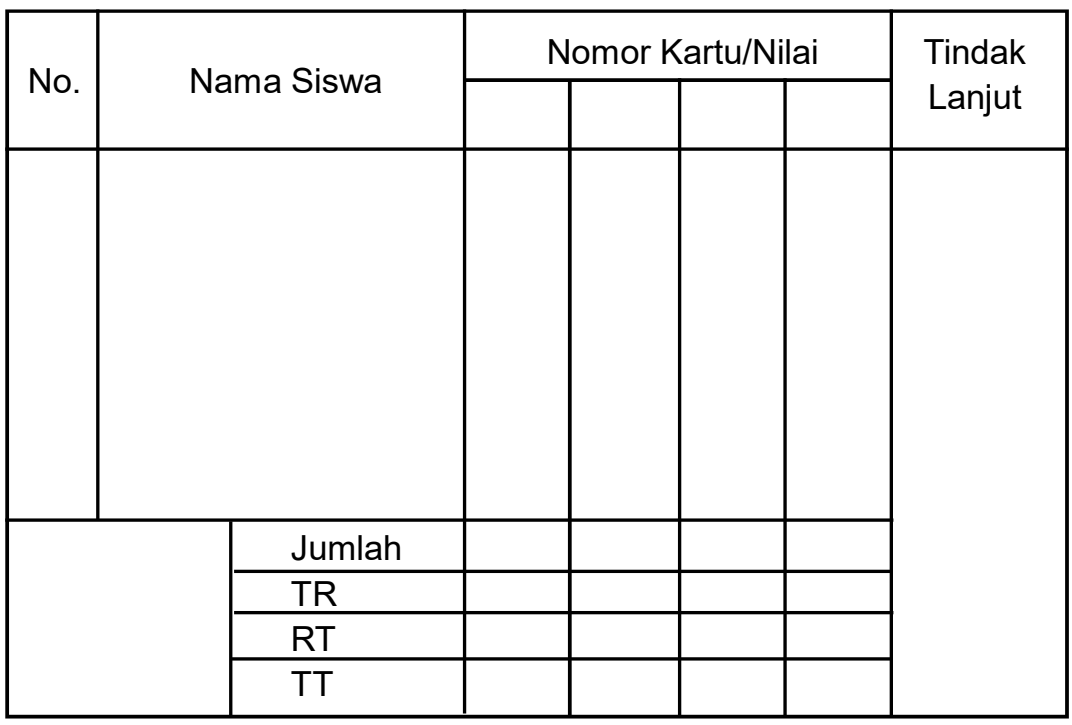

Keterangan:

TR = Nilai Tertendah

RT = Nilai Rata-rata

$\mathrm{TT}=$ Nilai Tertinggi

Guru Mata Pelajaran 
Lampiran 2: Contoh Seperangkat Kartu Kerja

\section{DAFTAR KARTU KERJA}

Mata Pelajaran : Matematika

Pokok Bahasan : 11.1 Segitiga

No. RP/SPB : XI - 1.11.1.1 Jenis-jenis Segitiga

Kelas/Cawu : I SLTP/3 (tiga)

Waktu : $2 \times 45$ menit

\begin{tabular}{|c|l|l|l|}
\hline No. & No. Kartu & \multicolumn{1}{|c|}{ Topik/Judul Kartu } & \multicolumn{1}{|c|}{ Jenis/Tingkatan } \\
\hline 1. & $13-01$ & Jenis-jenis Segitiga (1) & Pengembangan \\
2. & $13-02$ & Segitiga Siku-siku (1) & Pengembangan/Latihan \\
3. & $13-03$ & Segitiga Siku-siku (2) & Latihan \\
4. & $13-04$ & Jenis-jenis Segitiga (2) & Latihan \\
5. & $13-05$ & Penerapan Segitiga & Latihan/Pengayaan \\
6. & $13-06$ & Menyusun Bangunan & \\
& & (Tangram) & Pengayaan(Investigasi) \\
\hline
\end{tabular}




\section{Jenis-jenis Segitiga}

\section{DISKUSI KELAS}

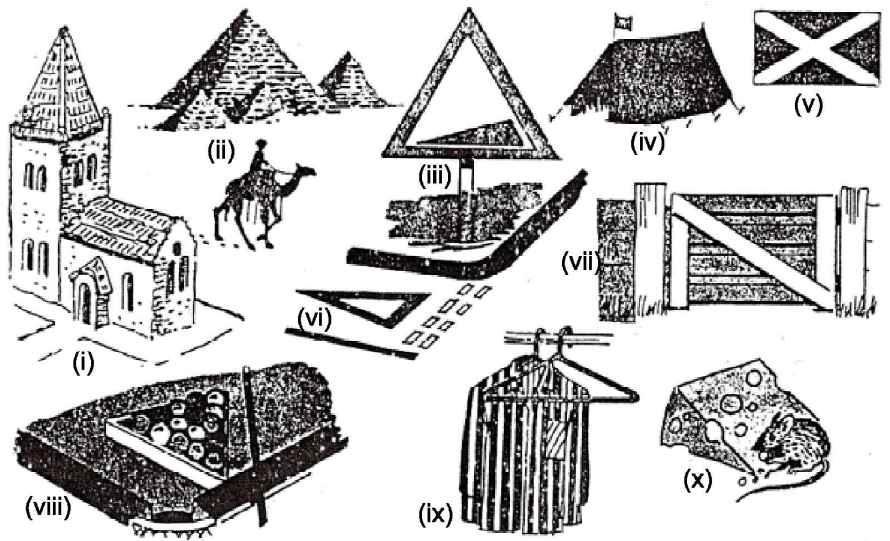

1. Bagian manakah pada bagian di atas berbentuk segitiga?

2. Dalam kenyataannya manakah segitiga-segitiga tersebut yang paling kecil, dan manakah yang paling besar?

3. a. Lihat gambar (vii) di tasa, papan yang menyilang pada pintu membuat pintu itu menjadi lebih kuat. Mengapa demikian?

b. Di mana lagi kamu melihat segitiga-segitiga yang diugunakan untuk memperkokoh suatu bangunan?

4.

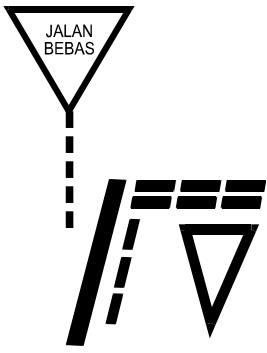

Mengapa segitiga di atas jalan raya lebih panjang dari segi tiga pada rambu-rambu lalu lintas? Perhatikan hal tersebut dan rambu-rambu lalau lintas lain dengan segitiga-segitiga

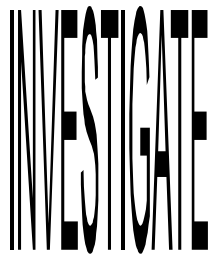
di sekitarnya. 


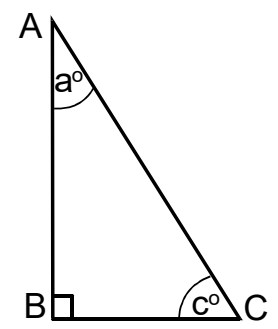

\section{Jumlah besar semua sudut segitiga adalah $180^{\circ}$}

$\triangle \mathrm{ABC}$ SIKU-SIKU

Jika $\angle A B C=90^{\circ}$ maka:

$\angle \mathrm{BCA}+\angle \mathrm{ACB}=90^{\circ}$

atau: $\mathrm{a}^{0}+\mathrm{c}^{0}=90^{\circ}$

\section{Latihan}

1. Medi menggunakan komputernya untuk mendapatkan pasangan sudut pada sebuah segitiga siku-siku. la mendapatkan pasangan yang tidak tepat. Pasangan manakah yang benar?

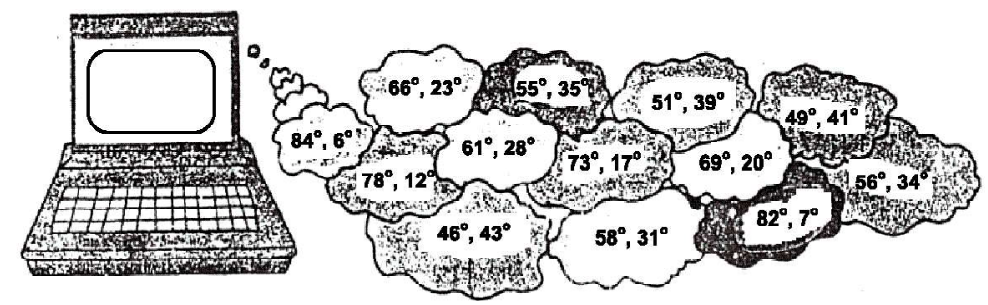

2. Mana yang segitiga siku-siku?

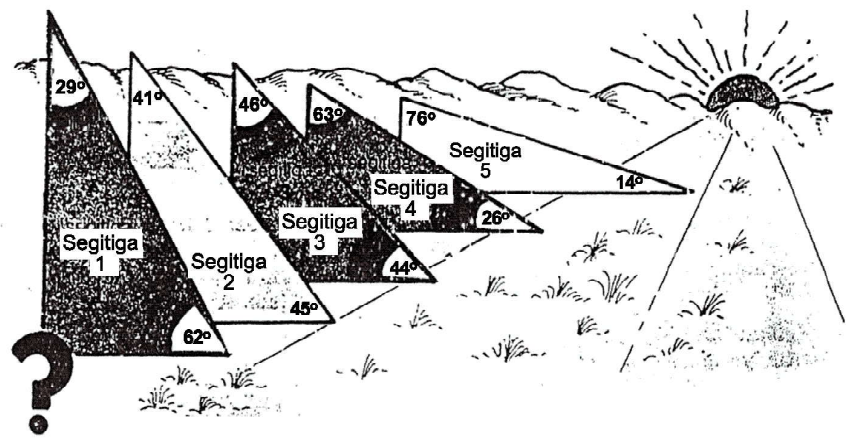


1. Manakah dari segitiga-segitiga ini yang berupa segitiga sikusiku?

a.

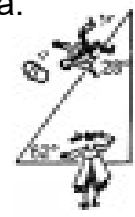

d.

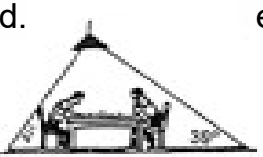

g.

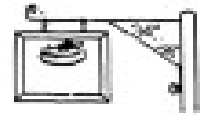

b.

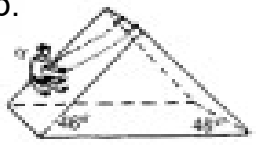

e.

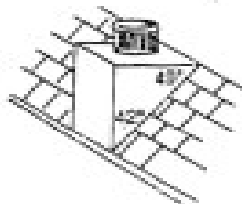

h.

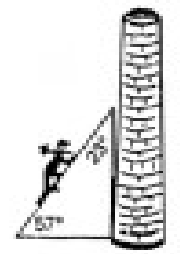

C.

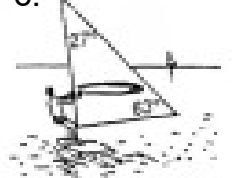

f.

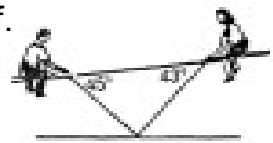

i.

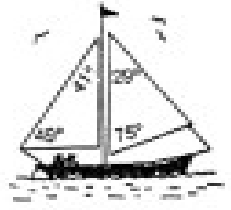

2. Hitung besar sudut-sudut yang ditandai dengan huruf. Misal $a^{\circ}=30^{\circ}$.

a.

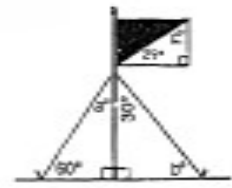

d.

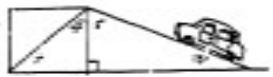

b.

e.
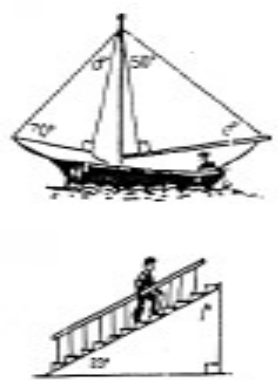

c.

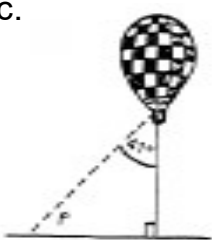

f.

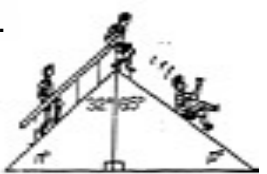


1. Isilah titik berikut ini.

Ketiga sudut suku-siku berjumlah ...

Sehingga: $a^{0}+b^{0}=\ldots{ }^{\circ}$

$$
\begin{aligned}
& \mathrm{c}^{\circ}+\mathrm{d}^{\circ}=\ldots{ }^{\circ} \\
& \mathrm{a}^{\circ}+\mathrm{b}^{\circ}+\mathrm{c}^{\circ}+\mathrm{d}^{\circ}=\ldots{ }^{\circ} \\
& \downarrow \\
& \angle \mathrm{A}+\angle \mathrm{B}+\angle \mathrm{C}=\ldots \circ
\end{aligned}
$$

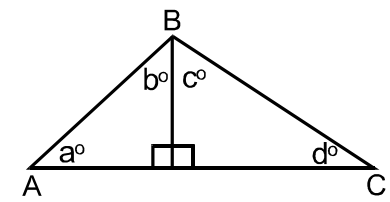

Besar sudut segitiga $A B C$ berjumlah ....

\section{Jumlah besar semua sudut segitiga adalah $180^{\circ}$}

2. Hitunglah besar sudut yang belum diketahui pada setiap segitiga ini. Sebutkanlah mana segitiga siku-siku, samakaki, bersudut lancip, atau bersudut tumpul.
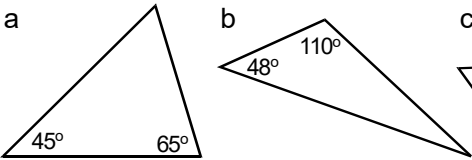

C

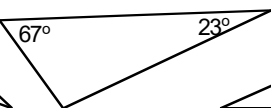

d

3. Tunjukkanlah segitiga yang siku-siku,samakaki, samasisi, siku-siku dan samakaki, ataukah bukan salah di antaranya.
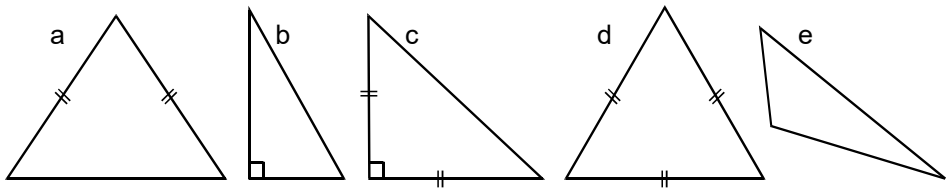

4. Jiplaklah segitiga-segitiga di atas yang mempunyai sumbu simetri, dan gambarlah sumbu simetrinya.

5. Bilangan-bilangan berapakah yang diwakili oleh huruf-huruf berikut ini?
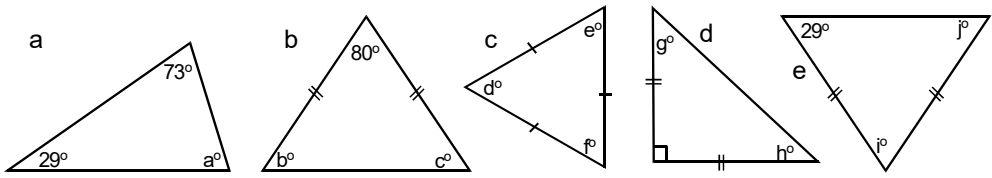
1.

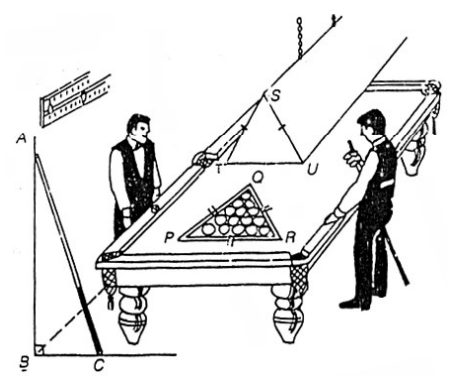

2.

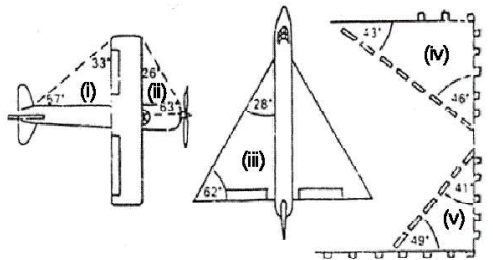

Jenis segitiga apakah ini?

$\triangle \mathrm{ABC}$

$\triangle P Q R$, jika $P Q=Q R=R P$

$\Delta \mathrm{STU}, \mathrm{jika} \mathrm{ST}=\mathrm{SU}$

Manakah dari segitigasegitiga ini yang siku-siku Berilah tanda 3 pada kolom "Ya" atau "Tidak"

(i)

(ii)

\begin{tabular}{|c|c|}
\hline Ya & Tidak \\
\hline & \\
\hline & \\
\hline & \\
\hline & \\
\hline
\end{tabular}

3.

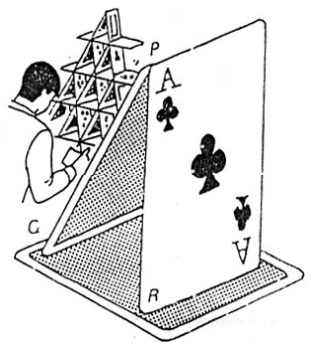

Lantai atas rumah kartu ini terbuat dari 2 kartu yang saling bersandar, dan satu kartu lagi sebagai alas sehingga terjadi $\triangle P Q R$.

a. Jenis segitiga apakah DPQR ini?

b. Panjang $P Q=7 \mathrm{~cm}$.

Berapakah panjang PR?

c. Jika $\angle \mathrm{QPR}=30^{\circ}$, berapakah besar $\angle \mathrm{PRQ}$ ? 
1. Banyak permainan, misalnya catur yang tidak diketahui lagi kapan diketemukan dan siapa penciptanya. Lain halnya dengan permainan "TANGRAM" yang telah berumu +4.000 tahun tetap diketahui penciptanya, yaitu seorang Cina bernama TAN dari Legenda.

Permainan ini tidak pernah berubah, tidak pernah berkembang, tetapi tetap disukai tua-muda.

Alat permaianan TANGRAM mudah dibuat, dan dengan alat itu dapat disusun berbagai bentuk menarik sesuai selera, imajinasi dan kreasi seseorang.

TANGRAM dipergunakan pula dalam teka-teki matematika sebagai latihan ketekunan, pengembangan akal, dan tidak mudah menyerah.

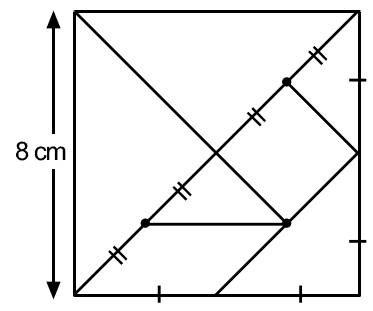

Dengan bahan kertas karton atau tripleks berbentuk persegi dan potong menurut garis-garis seperti pada gambar disamping akan diperoleh 7 (tujuh) keping yang disebut :TANGRAM"
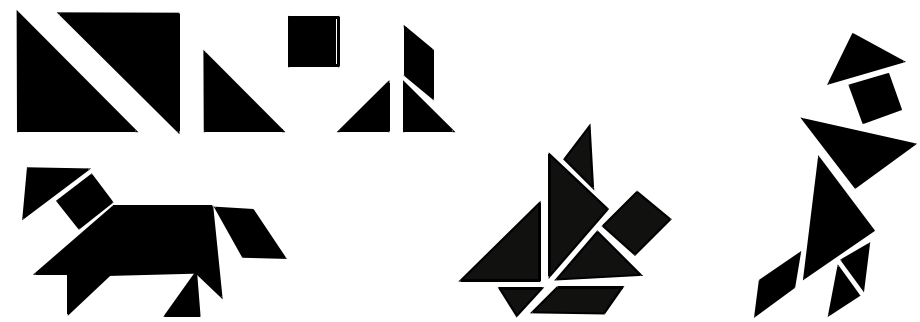

Tugas: Buatlah beberapa gambar/bentuk lagi menurut kreasimu, selain dari contoh diatas. 